\title{
Study on Sub-vehicle Cable Sealing Materials
}

\author{
Jianzhong $\mathrm{Hu}^{1}$, a \\ ${ }^{1}$ Department of Electromechanical Management, China Maritime Police Academy, Ningbo 315801 , \\ China \\ a13858365803@139.com
}

Keywords: Cable sealing; Sub-vehicles; Sealing materials; Polyurethane property modification

\begin{abstract}
Cable sealing is the key to cables installed in sub-vehicles. The existing cable sealing materials include rubber, polytetrafluoroethylene (PTFE), graphite, etc., among them polyurethane shows high potential of changing property. In this paper, we analyse the physical and chemical properties of three materials used in cable sealing, and give measures to modify the properties of polyurethane for the purpose of improving its sealing effect.
\end{abstract}

\section{Introduction}

When sub-vehicles are in deep water, cables installed would be under the threat of water leakage, which might result in danger to the crew and vehicles. Currently, cable sealing structures in sub-vehicles are mostly implemented by sealing materials. The advantages of the existing materials are simplicity, convenience, cheap cost and wide usage. The disadvantages are also obvious, namely poor sealing effect, heavy abrasion and short life span [1]. In order to satisfy the structure requirements of cable sealing, gasket rings are considered to be better alternative. In this paper, we mainly study the material selection for sealing gaskets.

\section{Characteristic Analysis of Sealing Materials}

Rubber. Rubber materials are a group of special materials. They have unique characteristics that could play a huge role in sealing structures:

a. The combination of Young's modulus E and major dislocation stretching ration (100\% or even higher) help rubber materials adjust into sealing structures and contact interfaces, while the contact stress remains within an acceptable range.

b. Theoretic limited Poisson's ratio (approaching 0.5) makes rubber disperse static stress equally to each dimension.

c. The rubber materials can be easily adjusted into cavity shapes because of low shear modulus G.

Table 1 shows properties and applications of some rubbers, and provides a reference to choosing available sealing rubber materials.

It is unavoidable to abrade gaskets in sealing process. However, thermoplastic polyurethane elastomer has a combined property from vulcanized rubber and common thermoplastic. thermoplasticpolyurethane elastomer features hardness and elasticity that can remain in good condition within a wide range of hardness (shore hardness $\mathrm{A}_{10} \sim \mathrm{D}_{75}$ ). When the hardness is the same, thermoplasticpolyurethane elastomer can bear more stress and its abrasion resistance is 2 10 times higher than natural rubbers. Excellent performance in oxygen and ozone resistance, oil and chemical corrosion resistance, heavy mechanical vibration resistance, etc. make thermoplasticelastical polyurethane a good cable sealing material that can be utilized in difficult conditions such as deep sub-vehicles.

Polytetrafluoroethylene. Polytetrafluoroethylene (PTFE) is polymerized by perfluoroethylene. It has advantages in chemical stability, corrosion-resistance, sealing property, adhesiveness and aging-resistance. It can even be used as anti-melt sealing gaskets in atomic bombs and cannonballs.

PTFE has the following characteristics that make it a perfect sealing material: 
Table 1 Properties and applications of rubbers

\begin{tabular}{|c|c|c|c|c|}
\hline Name & Advantage & Disadvantage & $\begin{array}{c}\text { Temperature } \\
{\left[{ }^{\circ} \mathrm{C}\right]}\end{array}$ & Application \\
\hline NR & $\begin{array}{l}\text { High elasticity, } \\
\text { stretching strength, } \\
\text { tear-resistance, } \\
\text { electricity insulation, } \\
\text { easy composite with } \\
\text { other materials }\end{array}$ & $\begin{array}{l}\text { Bad oxygen and ozone } \\
\text { resistance, aging; bad } \\
\text { chemical solvent (oil, } \\
\text { acid and alkali) } \\
\text { endurance }\end{array}$ & $-60 \sim 80$ & $\begin{array}{l}\text { Tyre, shoes, } \\
\text { pipe, cable } \\
\text { cover }\end{array}$ \\
\hline SBR & $\begin{array}{l}\text { Abrasion-resistance, } \\
\text { anti-aging and } \\
\text { heat-resistance } \\
\text { better than NR }\end{array}$ & $\begin{array}{l}\text { Low elasticity and } \\
\text { tear-resistance, bad } \\
\text { processing capability, } \\
\text { esp. adhesiveness }\end{array}$ & $-50 \sim 100$ & $\begin{array}{l}\text { Tyre, board, } \\
\text { pipe }\end{array}$ \\
\hline $\mathrm{CR}$ & $\begin{array}{l}\text { Oxygen } \\
\text { ozone-resistant, NOT } \\
\text { flammable, oil and other } \\
\text { chemical solvent } \\
\text { enduring, acid and alkali } \\
\text { adaptable, anti-aging } \\
\text { and airtight }\end{array}$ & $\begin{array}{l}\text { Bad coldness } \\
\text { endurance, poor } \\
\text { specific gravity and } \\
\text { electricity insulation, } \\
\text { high cost, difficult to } \\
\text { store, etc }\end{array}$ & $-45 \sim 100$ & $\begin{array}{l}\text { Cable cover, } \\
\text { molded } \\
\text { products, } \\
\text { sealing } \\
\text { gasket, } \\
\text { adhesiveness }\end{array}$ \\
\hline NBR & $\begin{array}{l}\text { Heat-resistant, airtight, } \\
\text { abrasion-resistant and } \\
\text { great adhesiveness }\end{array}$ & $\begin{array}{lr}\text { Poor strength and } \\
\text { elasticity, poor acid and } \\
\text { polarity } \\
\text { endurance, } \\
\text { insulation }\end{array}$ & $-30 \sim 100$ & $\begin{array}{l}\text { Oil pipe, } \\
\text { sealing } \\
\text { materials }\end{array}$ \\
\hline $\begin{array}{l}\mathrm{HN} \\
\mathrm{BR}\end{array}$ & $\begin{array}{lr}\text { High mechanical } \\
\text { strength } \\
\text { abrasion-resistance }\end{array}$ & High cost & $-30 \sim 150$ & $\begin{array}{l}\text { Oil and } \\
\text { heat-enduran } \\
\text { ce products }\end{array}$ \\
\hline FPM & $\begin{array}{l}\text { Beat oil and acid-alkali } \\
\text { endurance in RUBBER } \\
\text { family. Good electricity } \\
\text { insulation, mechanical } \\
\text { and chemical properties }\end{array}$ & $\begin{array}{l}\text { Poor processing } \\
\text { capability } \\
\text { ventilation, high cost }\end{array}$ & $-20 \sim 200$ & $\begin{array}{l}\text { Sealing } \\
\text { materials in } \\
\text { rocket, } \\
\text { aeroplane, car } \\
\text { and pipe }\end{array}$ \\
\hline AU/EU & $\begin{array}{l}\text { Best abrasion-resistance } \\
\text { in RUBBER family. } \\
\text { Good strength, } \\
\text { elasticity, oil and ozone } \\
\text { resistance, anti-aging, } \\
\text { airtight }\end{array}$ & $\begin{array}{l}\text { Poor water and alkali } \\
\text { endurance, poor organic } \\
\text { solvent endurance }\end{array}$ & $-30 \sim 80$ & $\begin{array}{l}\text { Gaskets, tyre, } \\
\text { shock-proof } \\
\text { products }\end{array}$ \\
\hline
\end{tabular}

(1) Mechanical property. The friction coefficient is extremely small, which is only one-fifth of polyethylene. Meanwhile, the acting force between $\mathrm{C}$ and $\mathrm{F}$ molecules are also extremely low, therefore this material has low viscosity. Its mechanical property remains wonderful within the temperature range of $-196^{\circ} \mathrm{C} \sim 260^{\circ} \mathrm{C}$. When all carbon bonds are occupied by fluorine, the compound does not turn fragile at low temperature.

(2) Chemical and environmental resistance. PTFE is resistant to any chemical corrosion except melt alkali metal (which is hardly found in cables). It can withstand concentrated sulfuric acid, nitric acid, hydrochloric acid and even boiling chloroazotic acid. PTFE is not flammable, and does not absorb moisture. Its property remains stable when exposed to oxygen and ultraviolet rays. In conclusion, it has fantastic chemical and environmental resistance. 
Graphite. Besides the above two materials, graphite can also be taken into consideration. Graphite is an abundant natural resource as well as a natural solid lubricant. It has layer structure that allows alkali metal, metal halide and oxidizing acid to embed between layers. Dilated graphite is called the "sealing king" after the chemical or electrical process. It features sealing reliability, flexibility, convenience, longevity and low leakage, etc.

There are mainly two categories of graphite sealing products: soft seal and hard seal. When graphite is compounded with polymer organic chemicals, it can be strengthened as special seal. When compounded with elastic polyurethane, graphite can be used as oil pumper sealing gaskets. When compounded with PTFE, graphite can be used as valve sealing gaskets.

In brief, the above three materials are desired sealing materials. However, PTFE has low potential of changing property to adjust into different sealing structures. In addition, graphite is easily obtained and cheap, and can be used as additive agent to improve other material's properties. Therefore in the next section, we focus on property improvement of polyurethane material.

\section{Polyurethane Modification}

Modification is an effective way to improve material properties. Polyurethane material has some flaws such as low temperature adaptability and poor surface performance, however these flaws can be rectified by modification. Biological degradation polyurethane elastomer is a product that can utilize the natural structure and properties of biology resources to produce materials like timber that can be degraded by microorganism.

Polyurethane Alloy. It is a new field of study, and researchers concern to complement properties of relevant polymer materials.

Damping polyurethane elastomer has a great damping effect when used for gaskets, loops and buffers. This material has extensive application in precise device, medical device, office appliance and electronic computers. It can stand evil environment for a long time and remain its outstanding properties such as damping effect, mechanical intensity, shape stability, ozone and ultra-violet ray resistance in low temperature condition $\left(-17.8^{\circ} \mathrm{C} \sim 4.5^{\circ} \mathrm{C}\right)[2]$.

Processing Method Modification. Besides modifying internal properties of polyurethane materials, modifying processing method sometimes can be more effective. For example, spray coating is one possible way, but raw materials should better be in fluid form.

Polyurethane Composite. It is made by adding surface modified particles and fibers in pre-poly phase. Polyurethane modulus can be improved by firmness of fibers without losing its elasticity [3,4]. Carbon fiber is an excellent additive to make polyurethane composite, which can improve abrasion-resistance, heat stability as well as flexibility [5].

Mixing different kinds of particles and powder in pure polyurethane to make powder-form composite is another modification method. Nowadays, nano-composite is a heated field. Some distinguished organic powder bases are nano $\mathrm{SO}_{2}[6], \mathrm{C}_{\mathrm{a}} \mathrm{CO}_{3}$ [7 9] and fiberglas [10], etc.

\section{Summary}

Polyurethane is the most suitable cable sealing material in rubber family, PTFE is the only plastic material that is possible as special sealing material. Graphite is perfect sealing material, however not suitable in cable gland structure of deep sub-vehicles. Polyurethane has high potential of being modified to cater for different sealing structure and environment. Multi-composite materials usually display better sealing effect than mono-composite materials. Polyurethane can act as an excellent base for a large group of additive agents. 


\section{Acknowledgements}

This work was supported by the Foundation for 2016 Higher Education Class Teaching Reform Project of Zhejiang, China under Grant No. kg20160499, the Foundation for Research Development Fund Project of China Maritime Police Academy, China under Grant No. 2015YYXMB04, the Foundation for General Research Project of Education Department of Zhejiang, China under Grant No. Y201636245.

\section{References}

[1] W.Z. Cao: Methods of sealing process and their application of ship cable dedicated channel, China Shiprepair, Vol. 26 (2013) No.2, p. 28-30 (In Chinese).

[2] W.M. Yu and T. Gong: The development and future of elastic polyurethane, Polyurethane Industry, Vol. 13 (1998) No.1, p. 1-5.

[3] Y.T. Zhao: Composite Material Polymer Base (Wuhan Poly-technic University Press, China 1992).

[4] R. Wang: Composite Material Polymer Base and Process (Science Press, China 2004).

[5] N. Yin, M.Q. Kang and L.M. Zhang, Reinforcement of carbon fiber on polyurethane elastomer, China Synthetic Rubber Industry, Vol. 21 (1998) No.1, p. 41-44.

[6] Y. Zhang and W.S. Hou: Nano- $\mathrm{S}_{\mathrm{i}} \mathrm{O}_{2}$ surface modification and its application in polyurethane elastomer, Functional Material, Vol. 8 (2006) No.37, p. 1286-1288.

[7] J. Suwanprateeb: Rate-dependent function in the correlation between hardness and yield stress of polyethylene composite, Polymer Composite, Vol. 21 (2000) No.2, p. 238-244.

[8] Q. Fu and G.H. Wang: Polyethylene toughened by rigid inorganic particles, Polymer Engineering and Science, Vol. 32 (1992) No.2, p. 94-97.

[9] T. Labour, C. Gauthier, R. Seguela, et al: Influence of the crystal in phase on the mechanical properties of unfilled and $\mathrm{C}_{\mathrm{a}} \mathrm{CO}_{3}$-filled polypropylene, Structural and Mechanical Characterization Polymer, Vol. 42 (2001) No.16, p. 7127-7135.

[10] H.B. Zhang and X.J. Yang: Influence of smash fiber to polypropylene mechanical property, Plastic Industry, Vol. 34 (2006) No.1, p. 45-47. 